\title{
Growth and Survival of 'Whitespire' Japanese Birch Grafted on Rootstocks of Five Species of Birch
}

\author{
Thomas G. Ranney and Everett P. Whitman, II \\ Department of Horticultural Science, Mountain Horticultural Crops Research \\ and Extension Center, North Carolina State University, 2016 Fanning Bridge \\ Road, Fletcher, NC 28732-9216 \\ Additional index words. Betula nigra, Betula papyrifera, Betula pendula, Betula platyphylla \\ var. japonica 'Whitespire', Betula szechuanica, graft compatibility, nursery production
}

\begin{abstract}
A 3-year study was conducted to evaluate growth and survival of trees grafted onto five species of birch rootstocks. 'Whitespire' Japanese birch (Betula platyphylla var. japonica Hara.) was grafted onto paper birch (B. papyrifera Marsh), European birch (B. pendula Roth), river birch (B. nigra L.), Szechuan birch [B. szechuanica (C. Schneid.) Janson], and 'Whitespire' Japanese birch rootstocks and grown under field conditions. Trees grafted onto river, European, paper, and 'Whitespire' birch rootstocks had similar $(100 \%$ to $60 \%)$ survival rates. Trees on Szechuan rootstock had a survival rate of $30 \%$, which was lower than that of all other rootstocks, except 'Whitespire'. 'Whitespire' scions grafted onto European birch rootstocks had thicker trunks, were higher, and had wider canopies than trees grafted onto 'Whitespire' rootstocks. Trees on river birch rootstocks also had thicker trunks but similar tree heights and canopy widths as trees grafted onto 'Whitespire'. 'Whitespire' Japanese birch rootstocks produced more rootstock suckers than any of the other rootstocks, while trees on river birch rootstocks had the most frost cracks. No signs of graft incompatibility were observed for any of the graft combinations. These results demonstrate that growth of 'Whitespire' birch can be enhanced by grafting this cultivar on rootstocks of other species, including European and river birch.
\end{abstract}

The genus Betula $(\mathrm{L}$.$) includes arborescent$ species native to a broad range of latitudes, climates, and habitats (The New Royal Horticultural Society, 1992). Within this genus, 'Whitespire' Japanese birch has been tolerant to heat and drought (Ranney et al., 1991; Ranney and Peet, 1994), but intolerant of poorly drained soils (Hasselkus, 1984). Research with container-grown trees has shown that grafting 'Whitespire' Japanese birch onto river birch and, to a lesser extent, on European birch rootstocks can enhance flood tolerance over trees on 'Whitespire' rootstocks (Ranney and Bir, 1994). The objectives of this study were to evaluate survival, growth, rootstock suckering, and short-term graft compatibility of 'Whitespire' Japanese birch scions on five species of rootstocks under field conditions.

Received for publication 14 Apr. 1994. Accepted for publication 4 Dec. 1994. The research reported in this publication was funded in part by the North Carolina Agricultural Research Service (NCARS), Raleigh, and the nursery industry through contributions to the Horticultural Research Institute, Washington, D.C. Use of trade names in this publication does not imply endorsement by NCARS of products named nor criticism of similar ones not mentioned. Technical assistance of personnel at the Mountain Horticultural Crops Research Station is gratefully acknowledged. The cost of publishing this paper was defrayed in part by the payment of page charges. Under postal regulations, this paper therefore must be hereby marked advertisement solely to indicate this fact.
Trees were grown at the North Carolina State Univ. (NCSU) Mountain Horticultural Crops Research Station, Fletcher. 'Whitespire' scions were grafted onto potted seedlings $(\approx 0.3$ $\mathrm{cm}$ in basal stem diameter) of river, paper, European, Szechuan, and 'Whitespire' Japanese birch in Feb. 1990 and 1991. The grafted trees were grown in containers until they were planted in the field during Spring 1991. Ten trees of 'Whitespire' Japanese birch grafted onto each of the five rootstocks were planted at a spacing of $4.5 \times 6.1 \mathrm{~m}$ in a randomized complete-block design with trees assigned to blocks according to tree size and age (all trees in a given block were of the same age). Trees ranged in height from 0.5 to $1.2 \mathrm{~m}$ in height at planting. Fertilizer and weed control followed standard recommended practices (NCSU, 1991). Supplemental irrigation was provided as needed.

Tree heights, canopy widths, and trunk diameters (15 cm aboveground) were measured in Dec. 1993. The number of frost cracks per tree was counted in Mar. 1993. Rootstock suckers (late-formed shoots arising from the rootstock) were counted and removed by pruning to ground level in July and November of each year. Total cumulative rootstock suckers were the total number of suckers removed. Soil $\mathrm{pH}$ was measured before planting in 1991. Soil texture and percolation rate (Craul, 1992) were tested in Feb. 1994. The field soil was classified as a sandy clay loam (49\% sand, $26 \%$ silt, and $25 \%$ clay), with a mean percolation rate of $2.3 \mathrm{~cm}$ per hour and an initial $\mathrm{pH}$ of 6.6.

Data were subjected to an analysis of variance. Comparison of means were based on Fisher's least significant difference test, $P \leq$ 0.05 .

No signs of graft union incompatibility (e.g., mechanically weak unions) were observed. However, occasional death of trees on some rootstocks occurred throughout the study (Table 1). Trees grafted onto river, European, paper, and 'Whitespire' rootstocks had similar survival rates. Only $\approx 30 \%$ of the trees on Szechuan rootstocks survived, significantly fewer than on all other rootstocks, except 'Whitespire' Japanese birch.

'Whitespire' scions grafted onto European birch rootstocks had larger trunk diameters, were higher, and had wider canopies than trees grafted onto 'Whitespire' rootstocks (Table 1). Trees on river birch rootstocks also had larger trunk diameters, but similar heights and canopy widths, than trees grafted onto 'Whitespire'. Trees grafted onto paper and Szechuan birch rootstocks had similar trunk diameters, heights, and canopy widths as trees on 'Whitespire' rootstocks.

Frost cracks occurred in Mar. 1993 on the lower trunk of the 'Whitespire' scion on some rootstocks (Table 1). A 45-cm snowfall, followed by a sunny day and then a cold night $(-18 C)$ on 3 Mar. 1993 resulted in bark splitting, typically on the south and southwest side of the trunk. Trees on river birch rootstocks had the greatest incidence of cracking, while trees on European and Szechuan birch rootstock had no cracking. The greater incidence of frost cracks on scions grafted on river birch rootstock suggests that it may be influencing cold hardiness of the scion.

Plants on 'Whitespire' Japanese birch rootstocks had a mean of 11.1 cumulative rootstock suckers, which was significantly more than with any other rootstock (Table 1). The remaining rootstocks had a similar $(\leq 3.5)$ mean number of cumulative rootstock suckers per tree.

Table 1. Mean tree survival, trunk diameter, height, canopy width, and cumulative number of rootstock suckers per plant following the growing seasons of 1991 through 1993 in the field for Betula platyphylla var. japonica 'Whitespire' grafted on five rootstocks.

\begin{tabular}{lclcccc}
\hline \hline & $\begin{array}{c}\text { Survival } \\
(\%)\end{array}$ & $\begin{array}{c}\text { Trunk } \\
\text { diam } \\
(\mathrm{cm})\end{array}$ & $\begin{array}{c}\text { Tree } \\
\mathrm{ht} \\
\text { Rootstock }\end{array}$ & $\begin{array}{c}\text { Canopy } \\
\text { width } \\
(\mathrm{m})\end{array}$ & $\begin{array}{c}\text { Frost } \\
\text { cracks } \\
(\text { no. })\end{array}$ & $\begin{array}{c}\text { Cumulative } \\
\text { rootstock suckers } \\
(\text { no. })\end{array}$ \\
\hline River & $100 \mathrm{a}^{\mathrm{z}}$ & $6.2 \mathrm{ab}$ & $3.27 \mathrm{ab}$ & $1.29 \mathrm{~b}$ & $1.0 \mathrm{a}$ & $1.4 \mathrm{~b}$ \\
European & $80 \mathrm{a}$ & $7.6 \mathrm{a}$ & $3.50 \mathrm{a}$ & $1.93 \mathrm{a}$ & $0.0 \mathrm{bc}$ & $3.5 \mathrm{~b}$ \\
Paper & $80 \mathrm{a}$ & $4.8 \mathrm{bc}$ & $3.32 \mathrm{ab}$ & $1.37 \mathrm{~b}$ & $0.3 \mathrm{~b}$ & $0.2 \mathrm{~b}$ \\
Whitespire & $60 \mathrm{ab}$ & $4.4 \mathrm{c}$ & $2.90 \mathrm{~b}$ & $1.46 \mathrm{~b}$ & $0.6 \mathrm{~b}$ & $11.1 \mathrm{a}$ \\
Szechuan & $30 \mathrm{~b}$ & $5.8 \mathrm{a}-\mathrm{c}$ & $2.92 \mathrm{~b}$ & $1.55 \mathrm{ab}$ & $0.0 \mathrm{bc}$ & $1.1 \mathrm{~b}$ \\
\hline
\end{tabular}

${ }^{\mathrm{z}}$ Means followed by the same letter within a column are not significantly different, $\mathrm{LSD}_{0.05}$. 
Interveinal leaf chlorosis was observed for trees on river birch rootstock the first 2 years in the field and appeared to result from $\mathrm{Fe}$ deficiencies due to the relatively high initial soil $\mathrm{pH}$ of 6.6. River birch grown on its own roots can develop leaf chlorosis in soils with $\mathrm{pH}>6.5$ (Dirr, 1990). Results from our study indicate that this is a characteristic retained by the river birch rootstock and that use of river birch rootstocks is probably best reserved for acidic soils (i.e., $\mathrm{pH}<6.5$ ).

The effect of rootstock on tree growth and survival can result from differences in rootstock adaptability to edaphic, climatic, and biotic components of the rhizosphere as well as physiological interactions between the rootstock and scion (Cummins and Aldwinckle, 1983). However, it is likely that the better growth of trees on river and European birch rootstocks resulted from better adaptability to our growing conditions. The soil in this study was a sandy clay loam with moderately slow percolation (U.S. Dept. of Agriculture, 1971). Paper birch and Japanese birch are known to be less tolerant of poorly drained soils than are river and European birches (Ranney and Bir, 1994). These differences in tolerance to excess moisture and low aeration may, in part, account for the enhanced growth of trees grafted on river and European birch rootstocks in this experiment.

The results from this study are specific to the rootstock genotypes included in this experiment, and the potential exists for considerable variation within these species. However, this study demonstrated that under certain conditions, growth of 'Whitespire' birch can be enhanced by grafting this cultivar on rootstocks of other species, including European and river birch.

\section{Literature Cited}

Craul, P.J. 1992. Urban soil in landscape design. Wiley, New York.

Cummins, J.N. and H.S. Aldwinckle. 1983. Breeding apple rootstocks, p. 294-394. In: J. Janick (ed.). Plant breeding reviews. AVI, Westport, Conn.
Dirr, M.A. 1990. Manual of woody landscape plants: Their identification, ornamental characteristics, culture, propagation and uses. 4th ed. Stipes, Champaign, Ill.

Hasselkus, E. 1984. Introducing Betula platyphylla 'Whitespire'. Arnoldia 44:36-38.

North Carolina State University. 1991 North Carolina agricultural chemicals manual. North Carolina State Univ., Raleigh.

Ranney, T.G. and R.E. Bir. 1994. Comparative flood tolerance of birch rootstocks. J. Amer. Soc. Hort. Sci. 119:43-48.

Ranney, T.G., R.E. Bir, and W.A. Skroch. 1991. Comparative drought resistance among six species of birch (Betula): Influence of mild water stress on water relations and leaf gas exchange. Tree Physiol. 8:351-360.

Ranney, T.G. and M.M. Peet. 1994. Heat tolerance of five taxa of birch (Betula): Physiological responses to supraoptimal leaf temperatures. J. Amer. Soc. Hort. Sci. 119:243-248.

The New Royal Horticultural Society. 1992. Dictionary of gardening. vol. 1. Stockton Press, New York.

U.S. Department of Agriculture. 1971. Guide for interpreting engineering uses of soils. U.S. Govt. Printing Office, Washington, D.C. 